\title{
Surgical treatment of small-sized non-small cell lung cancer-a dilemma for surgeons
}

\author{
Ken Kodama ${ }^{1}$, Masashi Takeda ${ }^{2}$ \\ ${ }^{1}$ Department of Thoracic Surgery, ${ }^{2}$ Department of Pathology, Yao Municipal Hospital, Osaka, Japan \\ Correspondence to: Ken Kodama, MD. Director Extraordinaire, Department of Thoracic Surgery, Yao Municipal Hospital, 1-3-1 Ryuge-cho, Yao City, \\ Osaka 581-0069, Japan. Email: cfaem800@jtw.zaq.ne.jp. \\ Comment on: Mimae T, Okada M. Are segmentectomy and lobectomy comparable in terms of curative intent for early stage non-small cell lung \\ cancer? Gen Thorac Cardiovasc Surg 2020;68:703-6.
}

Submitted Apr 12, 2020. Accepted for publication Apr 30, 2020.

doi: 10.21037/jtd-20-1651

View this article at: http://dx.doi.org/10.21037/jtd-20-1651

The review recently reported by Mimae and Okada made very important points about selecting the surgical procedure for patients with early stage non-small cell lung cancer (NSCLC) (1). A prospective randomized study showing the inferiority of sublobar resection compared with standard lobectomy was reported in 1995 (2). The result had a major impact on thoracic surgeons around the world. On the other hand, at that time, the utility of limited resection had been well-established in the fields of gastric and breast cancer. Therefore, we retrospectively analyzed the existence of candidates that could achieve long-term survival by sublobar resection if we restricted the target lung cancer patients to those with a tumor diameter of $2 \mathrm{~cm}$ or smaller among T1N0M0 cancers. Two years after the randomized study was reported, our results were published, in 1997 (3).

Afterwards, high-resolution computed tomography (HRCT) and fluorine-18-2-deoxy-D-glucose (FDG) positron emission tomography (PET) were introduced to preoperatively select the surgical procedure. The selection has been made by investigators based on the tumor location, tumor size, consolidation to tumor $(\mathrm{C} / \mathrm{T})$ ratio on HRCT, and maximum standardized uptake value (SUV max) on FDG-PET/CT. During the last quarter century, comparisons of oncologic outcomes among surgical procedures have been performed based on real-world data with long-term follow-ups. Results of propensity-matched analysis of survival and recurrence after segmentectomy versus lobectomy (selected studies) are listed in Table 1 (4-11). According to the results, there was no significant difference in survival and or local relapse-free survival between two groups, except in one report (9). Because surgical management of stage IA $(\leq 2 \mathrm{~cm})$ NSCLC leads to 5 -year survival rates as high as $80 \%$, decisions related to optimal surgical resection are critical to realize a meaningful chance of cure. However, the reported survival curves showed the existence of events such as cancer recurrence or death beyond 5 years, so a 10 -year follow-up would be necessary to compare the surgical procedures for stage $1 \mathrm{~A}$, NSCLC (6-10). According to the study of Nomori and coworkers (12), of 179 segmentectomies for cT1 $(\leq 3 \mathrm{~cm})$ N0M0 NSCLC, 8 patients developed local recurrences (5 at the surgical margin and 3 in the residual lobe). Of note, six of the 8 local recurrences developed more than 5 years after segmentectomy. Nishio and coworkers (9) performed re-assessment of the outcome of intentional extended segmentectomy for invasive $(\mathrm{C} / \mathrm{T}$ ratio $>0.5)$ cT1aN0 NSCLC, and demonstrated that segmentectomies for a lesion located in the superior or left upper lobe segment may be performed with a prognosis comparable to that of lobectomy.

Since 2009, the Japan Clinical Oncology Group (JCOG) and West Japan Oncology Group (WJOG) conducted a randomized, phase III trial on lobectomy versus limited resection (segmentectomy) for small invasive peripheral lung cancers with a diameter $\leq 2 \mathrm{~cm}$ (JCOG0802/ WJOG4607L) (13). Recently, a randomized trial showed no difference in the safety profile regarding almost all parameters of intra- and postoperative complications, except for segmentectomy being associated with a higher chance of air leak (14). However, the results of the primary end-point 
Table 1 A propensity-matched analysis of survival and recurrence after segmentectomy versus lobectomy (Selected studies)

\begin{tabular}{|c|c|c|c|c|c|c|}
\hline Study & Patients enrolled & Comparison & $\begin{array}{l}\text { No. of propensity } \\
\text { score matched pair }\end{array}$ & Endpoint & $\begin{array}{l}\text { Significant } \\
\text { difference }\end{array}$ & Significant findings \\
\hline $\begin{array}{l}\text { Wisnivesky } \\
\text { et al. } 2010 \text { (4) }\end{array}$ & $\begin{array}{l}\text { Stage IA, NSCLC } \\
\leq 20 \mathrm{~mm},>65 \text { years of } \\
\text { age }\end{array}$ & $\begin{array}{l}\text { Lobectomy vs. } \\
\text { limited resection } \\
\text { (segmentectomy or } \\
\text { wedge resection }\end{array}$ & $392: 196(2: 1)$ & $\begin{array}{l}\text { OS and lung cancer- } \\
\text { specific survival } \\
\text { (median follow-up = } \\
59 \text { months) }\end{array}$ & No difference & - \\
\hline $\begin{array}{l}\text { Altorki et al. } \\
2014 \text { (6) }\end{array}$ & $\begin{array}{l}\text { cStage IA, NSCLC } \\
<30 \mathrm{~mm} \text {, solid nodule }\end{array}$ & $\begin{array}{l}\text { Lobectomy vs. } \\
\text { sublobar resection } \\
\text { (segmentectomy or } \\
\text { wedge resection }\end{array}$ & $\begin{array}{l}\text { Sublobar resection: } \\
53 \text { patients }\end{array}$ & 10-y Kaplan-Meier & No difference & $\begin{array}{l}\text { No local recurrence } \\
\text { in segmentectomy } \\
\text { group }\end{array}$ \\
\hline $\begin{array}{l}\text { Kodama et al. } \\
2016(8)\end{array}$ & cT1aNOMO, NSCLC & $\begin{array}{l}\text { Lobectomy vs. } \\
\text { segmentectomy }\end{array}$ & 69 pairs & $\begin{array}{l}\text { 5- and 10-y OS and } \\
\text { RFS }\end{array}$ & No difference & $\begin{array}{l}3 \text { local recurrences } \\
\text { in segmentectomy } \\
\text { group (hilar or } \\
\text { mediastinal lymph } \\
\text { node) }\end{array}$ \\
\hline $\begin{array}{l}\text { Nishio et al. } \\
2016 \text { (9) }\end{array}$ & $\begin{array}{l}\text { cTlaNOMO, NSCLC, } \\
\mathrm{C} / \mathrm{T}>0.5\end{array}$ & $\begin{array}{l}\text { Lobectomy vs. } \\
\text { segmentectomy }\end{array}$ & 59 pairs & 5-y RFS & $\begin{array}{l}\text { Lesion site- } \\
\text { specific }\end{array}$ & $\begin{array}{l}\text { Superior and } \\
\text { left upper lobe } \\
\text { segmentectomy } \\
\text { may be preferred } \\
\text { with prognosis } \\
\text { comparable to } \\
\text { lobectomy }\end{array}$ \\
\hline $\begin{array}{l}\text { Kamel et al. } \\
2019 \text { (11) }\end{array}$ & $\begin{array}{l}\text { cStage IA } \\
\text { adenocarcinoma, } \\
\leq 30 \mathrm{~mm} \text {, } \\
\text { hypermetabolic } \\
\text { SUVmax } \geq 3\end{array}$ & $\begin{array}{l}\text { Lobectomy vs. } \\
\text { segmentectomy }\end{array}$ & $156: 46(4: 1)$ & $\begin{array}{l}\text { 5-y cancer-specific } \\
\text { survival and RFS }\end{array}$ & No difference & $\begin{array}{l}\text { Lobectomy better } \\
5 \text {-y OS than } \\
\text { segmentectomy } \\
(P=0.004)\end{array}$ \\
\hline
\end{tabular}

NSCLC, non-small cell lung cancer; y, year; OS, overall survival; RFS, recurrence-free survival; DFS, disease-free survival; C/T, consolidation to tumor ratio; SUVmax, maximum standardized uptake value.

(non-inferiority of overall survival in segmentectomy versus lobectomy) are still being awaited.

A recent prospective study (15) reported that occult lymph node metastasis was frequently identified in peripheral N1 stations (\#11-\#13) in a patient cohort with cT1b, SUVmax $\geq 1.7, \mathrm{C} / \mathrm{T}$ ratio $\geq 0.6$, N0 NSCLC, and concluded that hilar lymphadenectomy is essential for accurate staging in the management of patients with small cN0 NSCLC. On the other hand, Deng and coworkers (16) retrospectively analyzed 354 patients who underwent lobectomy with systematic mediastinal LN dissection or sampling for clinical T1N0M0 peripheral NSCLC, and indicated that the pattern of regional lymph node metastasis in clinical stage IA peripheral NSCLC was significantly 
influenced by the tumor size, which may provide evidence to determine the surgical choice (lobectomy, segmentectomy, or wedge resection) for these early-stage NSCLC patients based on the tumor size. Of note, in their cohort of patients with a tumor $\leq 1 \mathrm{~cm}$ in diameter $(\mathrm{n}=35)$, there was no lymph node metastasis in the lung, hilar region, or mediastinum.

According to the report of Cheng and coworkers (17), no patients with a histology of adenocarcinoma in situ, minimally invasive adenocarcinoma, or lepidic-predominant adenocarcinoma on final pathology had $\mathrm{pN} 2$ disease. If these subtypes were classified together as a low-risk group, the concordance rate between frozen section and final pathology diagnosis would be $88.9 \%$ in the retrospective test cohort. Thus, if frozen section diagnosis is made with an appropriate tumor specimen at the time of wedge resection, it may be very useful to decide on the need for procedural conversion to segmentectomy or lobectomy. Another important issue is the status of the surgical margin at sublobar resection. Since 1997, we have performed a novel intraoperative lavage cytologic technique to check the surgical margin status for sublobar resection to avoid margin recurrence, and published a preliminary report in 2003 (18). On the other hand, Kadota and coworkers (19) demonstrated that, in lung adenocarcinoma with tumor spread through air spaces (STAS), sublobar resection was correlated with a significantly higher risk of locoregional recurrence than lobectomy. However, it remains unclear whether cancer cells in the air space found on frozen section histology represent STAS or products caused by surgical manipulation. As the second step following decision-making based on the preoperative indicators, intraoperative frozen section histology and margin cytology are important for a final decision on the procedure in order to avoid margin recurrence, residual lobe recurrence, and regional lymph node metastasis.

We present a 58-year-old male patient (Figure 1) with unexpected extension after wide wedge resection of a subsolid tumor of $0.9 \mathrm{~cm}$ in diameter incidentally discovered in the apicoposterior segment $(\mathrm{S} 1+2)$ of the left upper lobe. Preoperative PET-CT demonstrated weak uptake of FDG with an SUV max of 1.3. The final pathology showed poorly differentiated adenocarcinoma with neither growth factor receptor gene mutation nor programmed cell death 1-ligand 1 (PD-L1) expression. One year after surgery, the patient developed left lower paratracheal (\#4L), subcarinal (\#7), and right hilar (\#11R) lymph node metastases. After histologic confirmation of metastatic adenocarcinoma by endoscopic ultrasound transesophageal needle aspiration, we conducted concurrent chemo-radiotherapy followed by immune checkpoint inhibitor therapy (Figure 1). Currently, he is alive with a good performance status three years after the surgery, although new left adrenal metastasis was recently discovered and the $2^{\text {nd }}$ line chemotherapy started.

What surgical procedure should have been adopted for this patient? Based on the tumor size and location on HRCT and preoperative SUV max of the tumor on PETCT, we chose wide wedge resection and cytologically identified a cancer-free at surgical margin. It should be taken into consideration that the accuracy of PET diagnosis is affected by the tumor size, and small lung cancer of $<1$ $\mathrm{cm}$ in diameter may lead to underestimation of the uptake of FDG due to the partial volume effect of the tumor, and may be judged as pseudonegative. As a result, the final pathology showed a poorly differentiated adenocarcinoma with a higher value of the Ki-67 index of 67.7 and vascular invasion, but without lymphatic invasion and infiltration to the visceral pleura. Pre- and intraoperative factors suggesting tumor aggressiveness were a $\mathrm{C} / \mathrm{T}$ ratio of nearly 1.0 and undifferentiated carcinoma based on frozen sectioning. However, he showed an unexpected postoperative course. Lymph node metastases had spread beyond the regional lymph node to the contralateral lung hilum. Our conclusion is that this patient was not indicated for surgery from the beginning of his diagnosis.

In conclusion, studies on the selection of surgical procedures for small-sized $(<2 \mathrm{~cm})$ NSCLC have yielded results excluding patients who are not indicated for surgery at the time of diagnosis, i.e., biologically aggressive behavior (cT1a-bN1-3). Surgeons must keep in mind that solid-type tumors with a $\mathrm{C} / \mathrm{T}$ ratio close to 1 include at least some patients with subclinical lymph node metastasis. Intraoperative frozen section histology with an appropriate specimen of the tumor in order to investigate histologic type, C/T ratio, grade (differentiation), and STAS, together with intraoperative resection margin cytology are essential to achieve a favorable outcome after segmentectomy.

\section{Acknowledgments}

Funding: None.

\section{Footnote}

Provenance and Peer Review: This article was commissioned and reviewed by the Section Editor Dr. Laura Chiara Guglielmetti (Cantonal Hospital Winterthur, Kantonsspital 

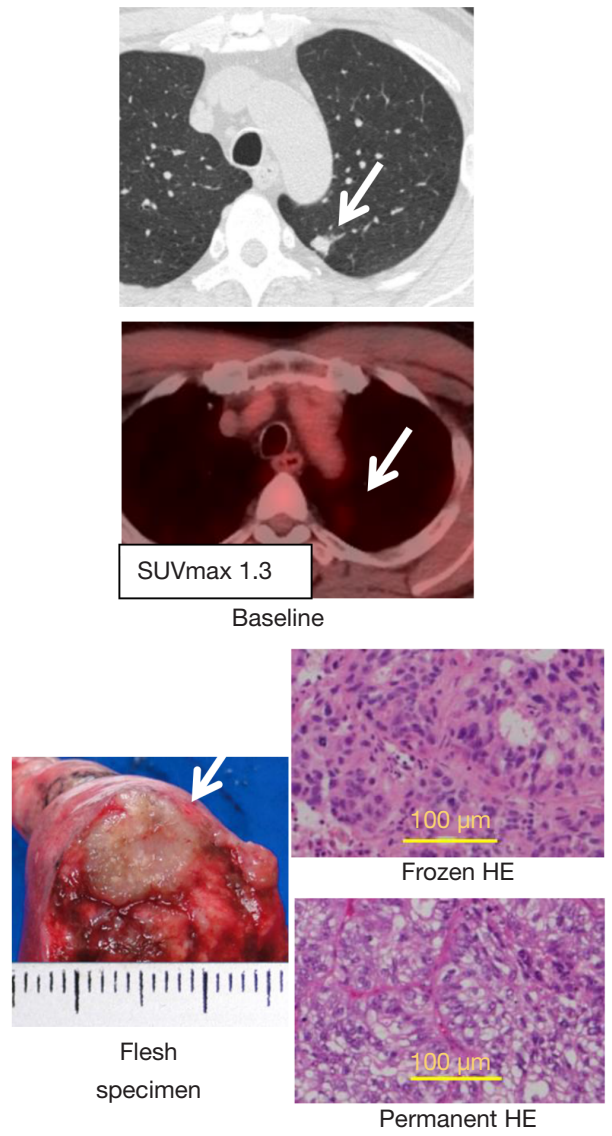

February 2017
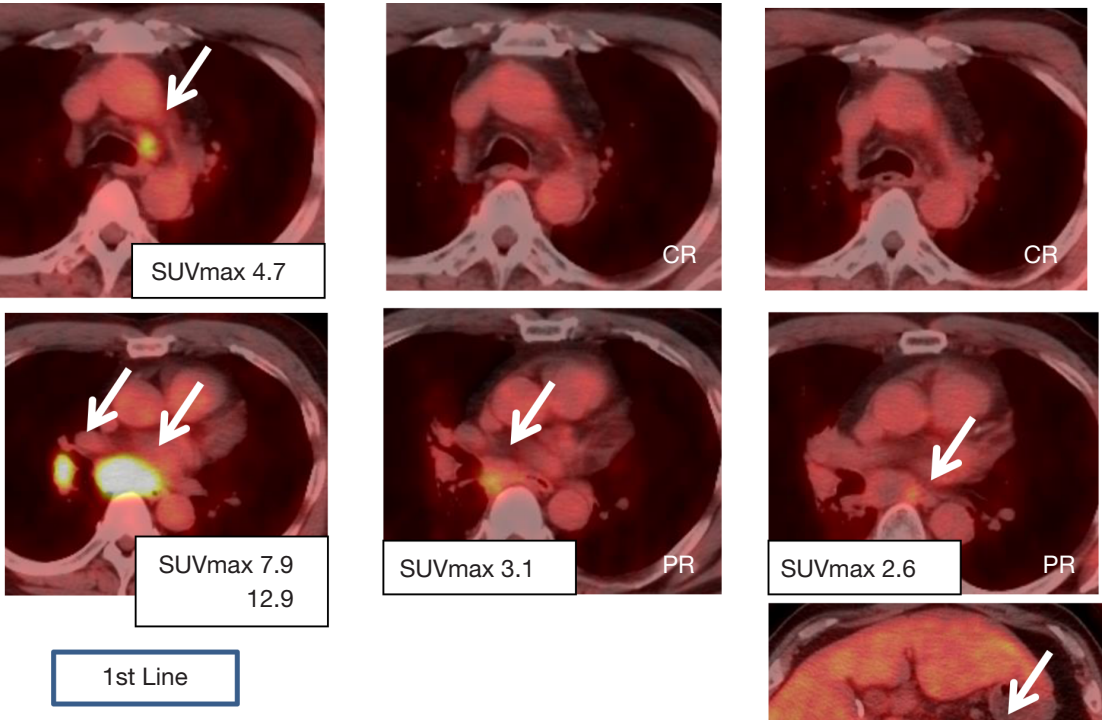

Concurrent

Chemo-RT CBDCA

$+$

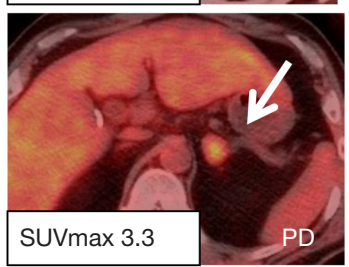

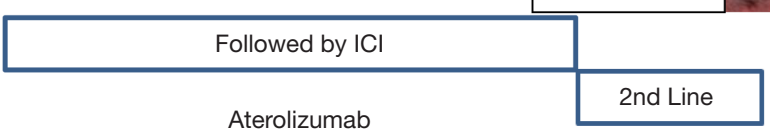

CBDCA + PEM

Ongoing

24 courses

February 2018

July 2019

February 2020

Figure 1 Timeline summarizing the clinical course and therapeutic interventions. SUVmax, maximum standardized uptake value; HE, hematoxylin and eosin; RT, radiation therapy; CBDCA, carboplatin; PTX, paclitaxel; ICI, immune checkpoint inhibitor; PEM, pemetrexed.

Winterthur, Switzerland).

Conflicts of Interest: Both authors have completed the ICMJE uniform disclosure form (available at http://dx.doi. org/10.21037/jtd-20-1651). The authors have no conflicts of interest to declare.

Ethical Statement: The authors are accountable for all aspects of the work in ensuring that questions related to the accuracy or integrity of any part of the work are appropriately investigated and resolved.

Open Access Statement: This is an Open Access article distributed in accordance with the Creative Commons Attribution-NonCommercial-NoDerivs 4.0 International License (CC BY-NC-ND 4.0), which permits the non- commercial replication and distribution of the article with the strict proviso that no changes or edits are made and the original work is properly cited (including links to both the formal publication through the relevant DOI and the license). See: https://creativecommons.org/licenses/by-nc-nd/4.0/.

\section{References}

1. Mimae T, Okada M. Are segmentectomy and lobectomy comparable in terms of curative intent for early stage non-small cell lung cancer? Gen Thorac Cardiovasc Surg 2020;68:703-6.

2. Ginsberg RJ, Rubinstein LV. Randomized trial of lobectomy versus limited resection for T1 N0 non-small cell lung cancer. Lung Cancer Study Group. Ann Thorac Surg 1995;60:615-22; discussion 622-3. 
3. Kodama K, Doi O, Higashiyama M, et al. Intentional limited resection for selected patients with T1 N0 M0 non-small-cell lung cancer: A single-institution study. J Thorac Cardiovasc Surg 1997;114:347-53.

4. Wisnivesky JP, Henschke CI, Swanson S, et al. Limited resection for the treatment of patients with stage IA lung cancer. Ann Surg 2010;251:550-4.

5. Tsutani Y, Miyata Y, Nakayama H, et al. Oncologic outcomes of segmentectomy compared with lobectomy for clinical stage IA lung adenocarcinoma: propensity score-matched analysis in a multicenter study. J Thorac Cardiovasc Surg 2013;146:358-64.

6. Altorki NK, Yip R, Hanaoka T, et al. Sublobar resection is equivalent to lobectomy for clinical stage $1 \mathrm{~A}$ lung cancer in solid nodules. J Thorac Cardiovasc Surg 2014;147:75462; discussion 762-4.

7. Landreneau RJ, Normolle DP, Christie NA, et al. Recurrence and survival outcomes after anatomic segmentectomy versus lobectomy for clinical stage I nonsmall-cell lung cancer: a propensity-matched analysis. J Clin Oncol 2014;32:2449-55.

8. Kodama K, Higashiyama M, Okami J, et al. Oncologic outcomes of segmentectomy versus lobectomy for clinical T1a N0 M0 non-small cell lung cancer. Ann Thorac Surg 2016;101:504-11.

9. Nishio W, Yoshimura M, Maniwa Y, et al. Re-assessment of intentional extended segmentectomy for clinical T1a N0 non-small cell lung cancer. Ann Thorac Surg 2016;102:1702-10.

10. Koike T, Kitahara A, Sato S, et al. Lobectomy versus segmentectomy in radiologically pure solid smallsized non-small cell lung cancer. Ann Thorac Surg 2016;101:1354-60.

11. Kamel MK, Rahouma M, Lee B, et al. Segmentectomy is equivalent to lobectomy in hypermetabolic clinical stage IA lung adenocarcinomas. Ann Thorac Surg

Cite this article as: Kodama K, Takeda M. Surgical treatment of small-sized non-small cell lung cancer-a dilemma for surgeons. J Thorac Dis 2020;12(10):6102-6106. doi: 10.21037/jtd20-1651
2019;107:217-23.

12. Nomori H, Mori T, Shiraishi A, et al. Long-term prognosis after segmentectomy for c'T1N0M0 non-small cell lung cancer. Ann Thorac Surg 2019;107:1500-6.

13. Nakamura K, Saji H, Nakajima R, et al. A phase III randomized trial of lobectomy versus limited resection for small-sized peripheral non-small cell lung cancer (JCOG0802/WJOG4607L). Jpn J Clin Oncol 2010;40:271-4.

14. Suzuki K, Saji H, Aokage K, et al. Comparison of pulmonary segmentectomy and lobectomy: Safety results of a randomized trial. J Thorac Cardiovasc Surg 2019;158:895-907.

15. Robinson EM, Ilonen IK, Tan KS, et al. Prevalence of occult peribronchial $\mathrm{N} 1$ nodal metastasis in peripheral clinical N0 small ( $<2 \mathrm{~cm})$ non-small cell lung cancer. Ann Thorac Surg 2020;109:270-6.

16. Deng HY, Zhou J, Wang RL, et al. Surgical Cchoice for clinical stage IA non-small cell lung cancer: view from regional lymph node metastasis. Ann Thorac Surg 2020;109:1079-85.

17. Cheng X, Zheng D, Li Y, et al. Tumor histology predicts mediastinal nodal status and may be used to guide limited lymphadenectomy in patients with clinical stage I non-small cell lung cancer. J Thorac Cardiovasc Surg 2018;155:2648-56.e2.

18. Higashiyama M, Kodama K, Takami K, et al. Intraoperative lavage cytologic analysis of surgical margins in patients undergoing limited surgery for lung cancer. J Thorac Cardiovasc Surg 2003;125:101-7.

19. Kadota K, Kushida Y, Kagawa S, et al. Limited resection is associated with a higher risk of locoregional recurrence than lobectomy in stage I lung adenocarcinoma with tumor spread through air spaces. Am J Surg Pathol 2019;43:1033-41. 